Journal of Clinical Investigation

Vol. 41, No. 7, 1962

\title{
THE EFFECT OF HYPERGAMMAGLOBULINEMIA ON ALBUMIN METABOLISM IN HYPERIMMUNIZED RABBITS STUDIED WITH ALBUMIN-I'131 *
}

\author{
BY MARCUS A. ROTHSCHILD, MURRAY ORATZ, EDWARD C. FRANKLIN \\ AND SIDNEY S. SCHREIBER
}

\author{
(From the Radioisotope Service, VA Hospital, the Department of Medicine, New York \\ University School of Medicine, and the Department of Biochemistry, \\ New York University College of Dentistry, New York, N. Y.)
}

(Submitted for publication January 24, 1962; accepted March 22, 1962)

Depressions of the serum albumin level are seen in clinical and in experimentally produced hyperglobulinemia (1-3); dextran infusions are also associated with hypoalbuminemia (4). However, the mechanisms for the production of these changes in albumin levels are not clearly defined. A colloid osmotic regulatory system has been postulated which effects control through either changes in plasma volume (1) or alterations in albumin metabolism (4). Previous studies employing dextran infusions supported the existence of a colloid osmotic regulatory mechanism in the control of serum albumin metabolism (4). The purpose of the studies reported here was to reexamine this hypothesis by measuring the rates of albumin synthesis and degradation during the development of induced hyperglobulinemia and after the attainment of this state.

\section{METHODS}

Female rabbits were used in all studies. The rabbits were kept in metabolism cages, and complete urine and stool collections were made daily. All rabbits were fed a standard rabbit diet. Two to three drops of Lugol's solution was administered daily in the rabbits' drinking water to inhibit thyroid uptake of $\mathrm{I}^{131}$.

The distribution and metabolism of albumin were measured by means of rabbit serum albumin labeled with $\mathrm{I}^{131}$. The procedures used to separate, purify, and iodinate the albumin have been described previously $(5,6)$. All lots of $\mathrm{I}^{131}$-albumin were tested in control rabbits to guard against the use of a preparation that contained a significant fraction of denatured material (5).

Seven rabbits received an injection of 50 to $75 \mu \mathrm{c}$ of albumin- $\mathrm{I}^{131}$ into an ear vein. Heparinized blood samples were obtained from the contralateral ear 6 and $10 \mathrm{~min}$ utes after the injection and at daily intervals thereafter. Control observations were made daily on the excretion

* This investigation was supported in part by Grants A-2489 and A-5141 from the United States Public Health Service and the Arthritis and Rheumatism Foundation. of radioactivity in urine and stool for 11 to 15 days. At the end of the control period, $3 \mathrm{ml}$ of a formalin-treated polyvalent pneumoccocal vaccine, containing $1 \times 10^{9}$ organisms per $\mathrm{ml}$, was injected intravenously every 3 days until the development of hyperglobulinemia and hypoalbuminemia ( 4 to 6 months). At this time the hyperimmunized rabbits received a second injection of albumin- $\mathrm{I}^{131}$, and observations of radioactivity in plasma, urine, and stool were made for 10 to 15 days while vaccine injections were continued. Four rabbits from this group were rested until the serum proteins had returned to control levels ( 3 to 5 months) and then received an injection of $300 \mu \mathrm{c}$ of albumin- $\mathrm{I}^{131}$ about 2 weeks before reinstitution of vaccine administration which lasted 26 to 34 days. Observations on albumin- $\mathrm{I}^{131}$ metabolism were continued throughout the period of immunization. Another injection of albumin- $\mathrm{I}^{131}$ was made at the end of immunization to remeasure albumin distribution and the total exchangeable albumin pool. Thus, albumin metabolism was first studied during what might be considered a relatively steady state during the long first immunization period. After the serum proteins had returned to normal values, albumin metabolism was studied in the changing state during an anamnestic response.

The pneumococcal vaccine was prepared from types I, II, VI, IX, XI, and XIV D, which previously had been passed through mice to assure virulence and good capsule formation (except XIV D, known to be avirulent for mice). Neopeptone broth cultures were then treated with formalin, washed with, and resuspended in saline. A final quelling test was performed. Mouse passage of stock pneumococcal cultures was performed every 3 months.

Plasma volume (PV) was determined from the mean space of distribution of the albumin- ${ }^{131}$ at 6 and $10 \mathrm{~min}-$ utes after injection. Total exchangeable albumin (TEA) was determined from the product of the space of distribution of the injected albumin- ${ }^{131}$ at distribution equilibrium and the plasma albumin concentration. The space of distribution of albumin- $\mathrm{I}^{131}$ is determined by dividing the amount of albumin- $\mathrm{I}^{131}$ remaining in the body (per cent of dose) by the plasma concentration of albumin- ${ }^{131}$ (per cent dose per milliliter). The amount remaining in the body at any time $t$ is the dose of $\mathrm{I}^{131}$ administered, less that execreted in the urine and stool to time $t$. Since under similar conditions, as used in these studies, we 
TABLE I

Albumin distribution *

\begin{tabular}{|c|c|c|c|c|c|c|c|c|}
\hline \multirow[b]{2}{*}{ Rabbit } & \multicolumn{2}{|c|}{ Weight } & \multicolumn{2}{|c|}{ Plasma volume } & \multicolumn{2}{|c|}{$\begin{array}{l}\text { Albumin } \\
\text { partition }\end{array}$} & \multicolumn{2}{|c|}{ TEAS } \\
\hline & $\mathrm{C}$ & $E$ & $\mathrm{C}$ & $\mathbf{E}$ & C & $\mathbf{E}$ & C & $\mathbf{E}$ \\
\hline no. & \multicolumn{2}{|c|}{ kg } & \multicolumn{2}{|c|}{$\begin{array}{c}m l / k g \\
\text { Primary immunization }\end{array}$} & \multicolumn{2}{|c|}{ \% i.v. } & \multicolumn{2}{|c|}{$m l / k g$} \\
\hline $\begin{array}{r}19 \\
26 \\
28 \\
86 \\
87 \\
101 \\
102\end{array}$ & $\begin{array}{l}6.5 \\
3.6 \\
3.3 \\
2.8 \\
4.0 \\
5.1 \\
5.1\end{array}$ & $\begin{array}{l}6.7 \\
4.1 \\
4.2 \\
3.2 \\
5.3 \\
5.3 \\
6.4\end{array}$ & $\begin{array}{l}40 \\
37 \\
34 \\
28 \\
40 \\
34 \\
37\end{array}$ & $\begin{array}{l}37 \\
38 \\
34 \\
37 \\
35 \\
36 \\
32\end{array}$ & $\begin{array}{l}40 \\
37 \\
37 \\
31 \\
36 \\
38 \\
38\end{array}$ & $\begin{array}{l}33 \\
37 \\
34 \\
37 \\
35 \\
34 \\
38\end{array}$ & $\begin{array}{r}100 \\
99 \\
92 \\
90 \\
110 \\
89 \\
98\end{array}$ & $\begin{array}{r}112 \\
101 \\
99 \\
100 \\
100 \\
104 \\
86\end{array}$ \\
\hline $\begin{array}{l}\text { Mean value } \\
\text { Change, \% }\end{array}$ & 4.3 & $\begin{array}{l}5.0 \\
16\end{array}$ & 36 & 36 & 37 & $\begin{array}{l}35 \\
-5.4\end{array}$ & 97 & $\begin{array}{l}100 \\
+3.1\end{array}$ \\
\hline \multicolumn{9}{|c|}{ Anamnestic response } \\
\hline $\begin{array}{l}19 \\
28 \\
86 \\
87\end{array}$ & $\begin{array}{l}6.8 \\
4.1 \\
3.2 \\
5.5\end{array}$ & $\begin{array}{l}7.2 \\
4.2 \\
3.1 \\
5.2\end{array}$ & $\begin{array}{l}34 \\
32 \\
32 \\
33\end{array}$ & $\begin{array}{l}44 \\
39 \\
42 \\
37\end{array}$ & $\begin{array}{l}35 \\
40 \\
35 \\
40\end{array}$ & $\begin{array}{l}42 \\
34 \\
32 \\
38\end{array}$ & $\begin{array}{l}96 \\
81 \\
91 \\
83\end{array}$ & $\begin{array}{r}105 \\
115 \\
130 \\
98\end{array}$ \\
\hline $\begin{array}{l}\text { Mean value } \\
\pm \text { SE } \\
\text { Change, \% }\end{array}$ & 4.9 & 4.9 & $\stackrel{33}{0.50}$ & $\begin{array}{r}41 \\
+2.6\end{array}$ & 38 & $\begin{array}{l}37 \\
-2.6\end{array}$ & $\begin{array}{l}88 \\
3.7\end{array}$ & $\begin{array}{r}112 \\
6.9 \\
+27\end{array}$ \\
\hline
\end{tabular}

* TEAS = total exchangeable albumin space, $\mathrm{C}=$ control study, $\mathrm{E}=$ experimental study.

have consistently accounted for 95 per cent or more of the administered dose in the urine and stool, other significant routes of excretion can be neglected. TEA is determined by assuming that the specific activity is uniform throughout the body after distribution. It can be shown that this assumption overestimates the TEA by no more than 6 to 7 per cent $(7,8)$. The fraction of the total exchangeable albumin pool located intravascularly was determined from the values for total plasma albumin and total exchangeable albumin. The rate of albumin degradation during the control and experimental periods was determined from the product of the renal clearance of $\mathrm{I}^{131}$ ( $\mu \mathrm{c} \mathrm{I}{ }^{131}$ excreted per day/ $\mu$ c albumin $I^{131}$ per ml plasma) released from degraded protein and the plasma albumin concentration. Fecal excretion of $\mathrm{I}^{131}$ during the periods of study did not amount to more than 3 to 4 per cent of the administered dose. This amount was included in the urinary excretion. This procedure, the metabolic clearance method, has the advantage of being valid even in nonsteady states and has been discussed previously $(5,7,9,10)$. During control periods plasma albumin concentrations remained constant. It was therefore assumed that steadystate conditions, with respect to albumin metabolism, existed and that the rate of albumin degradation equaled the rate of albumin synthesis. After hyperimmunization was achieved (4 to 6 months after the start of vaccination), plasma protein concentrations, although at new levels, remained relatively constant, and again albumin synthesis was assumed to approximate albumin degradation. The total amount of albumin degraded during the experimental and control periods was obtained from the sum of the daily values of the amount of albumin degraded, as determined by the clearance method.

In the four rabbits studied during the development of hypergammaglobulinemia in the anamnestic phase of immunization, control and experimental observations on albumin metabolism were made with a single dose of albumin- $\mathrm{I}^{131}$ so that control and experimental values for albumin degradation could be obtained consecutively. The net change in albumin synthesis was obtained from the difference between the total amount degraded during the control and immunization period and the change in the total exchangeable albumin pool as determined from the first and second injection of albumin- $\mathrm{I}^{131}$ (the latter used to determine albumin pool size and distribution).

Plasma, urine, and stool samples were assayed for $\mathrm{I}^{231}$ in a well-type scintillation counter with a sensitivity of

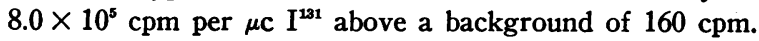
Total plasma protein was determined by a microKjeldahl method. Concentration of plasma albumin and the protein partition were determined by boundary electrophoresis employing a Kern microelectrophoretic unit as previously described (4). Some of the plasma samples were examined by paper electrophoresis, stained quantitatively with bromphenol blue, and protein partition was determined with a Spinco Analytrol (11).

\section{RESULTS}

Data pertaining to albumin distribution after the production of experimental hyperglobulinemia are presented in Table I. The rabbits showed a weight 
TABLE II

Data pertaining to plasma protein metabolism before and after immunization *

\begin{tabular}{|c|c|c|c|c|c|c|c|c|c|c|c|c|c|}
\hline \multirow[b]{2}{*}{ Rabbit } & \multicolumn{2}{|c|}{ Total protein } & \multicolumn{2}{|c|}{ Albumin } & \multicolumn{2}{|c|}{$\gamma$ Globulin } & \multicolumn{2}{|c|}{ TEA } & \multicolumn{2}{|c|}{$\begin{array}{c}\text { Albumin } \\
\text { degradation }\end{array}$} & \multirow{2}{*}{$\begin{array}{c}\text { Days } \\
\text { of } \\
\text { study } \\
E\end{array}$} & \multicolumn{2}{|c|}{$\begin{array}{l}\text { Albumin } \\
\text { synthesis }\end{array}$} \\
\hline & C & $\mathbf{E}$ & C & $\mathrm{E}$ & C & $\mathrm{E}$ & C & $\mathrm{E}$ & C & $\mathrm{E}$ & & C & $\mathrm{E}$ \\
\hline no. & \multicolumn{2}{|c|}{$\mathrm{g} / 100 \mathrm{ml}$} & \multicolumn{2}{|c|}{$\mathrm{g} / 100 \mathrm{ml}$} & \multicolumn{2}{|c|}{$\mathrm{g} / 100 \mathrm{ml}$} & \multicolumn{2}{|c|}{$\mathrm{g} / \mathrm{kg}$} & \multicolumn{2}{|c|}{$\mathrm{g} / \mathrm{kg} / \mathrm{day}$} & & \multicolumn{2}{|c|}{$\mathrm{g} / \mathrm{kg} / \mathrm{day}$} \\
\hline \multicolumn{14}{|c|}{ Primary immunization } \\
\hline $\begin{array}{r}19 \\
26 \\
28 \\
86 \\
87 \\
101 \\
102\end{array}$ & $\begin{array}{l}6.72 \\
6.54 \\
6.48 \\
6.13 \\
6.74 \\
6.53 \\
6.55\end{array}$ & $\begin{array}{c}7.51 \\
10.1 \\
9.00 \\
9.07 \\
8.20 \\
8.40 \\
8.75\end{array}$ & $\begin{array}{l}3.6 \\
3.9 \\
3.5 \\
3.6 \\
3.6 \\
3.9 \\
3.6\end{array}$ & $\begin{array}{l}2.7 \\
2.7 \\
2.7 \\
3.2 \\
3.0 \\
2.7 \\
2.5\end{array}$ & $\begin{array}{l}0.84 \\
0.65 \\
0.63 \\
0.93 \\
0.72\end{array}$ & $\begin{array}{l}3.0 \\
5.6 \\
4.5 \\
3.4 \\
3.0 \\
3.6 \\
3.6\end{array}$ & $\begin{array}{l}3.6 \\
3.9 \\
3.2 \\
3.3 \\
3.9 \\
3.5 \\
3.5\end{array}$ & $\begin{array}{l}3.0 \\
2.7 \\
2.7 \\
3.2 \\
3.0 \\
2.8 \\
2.1\end{array}$ & $\begin{array}{l}0.22 \\
0.22 \\
0.24 \\
0.22 \\
0.23 \\
0.28 \\
0.30\end{array}$ & $\begin{array}{l}0.17 \\
0.16 \\
0.20 \\
0.23 \\
0.19 \\
0.18 \\
0.17\end{array}$ & & & \\
\hline $\begin{array}{l}\text { Mean value } \\
\pm \text { SE } \\
\text { Change, \% }\end{array}$ & $\begin{array}{l}6.53 \\
0.08\end{array}$ & $\begin{array}{r}8.70 \\
0.31 \\
+33.2\end{array}$ & $\begin{array}{l}3.7 \\
0.06\end{array}$ & $\begin{array}{c}2.8 \\
0.09 \\
-24\end{array}$ & 0.75 & 3.8 & $\begin{array}{l}3.6 \\
0.1\end{array}$ & $\begin{array}{r}2.8 \\
0.1 \\
-22\end{array}$ & $\begin{array}{l}0.24 \\
0.012\end{array}$ & $\begin{array}{c}0.19 \\
0.091 \\
-17\end{array}$ & & & \\
\hline \multicolumn{14}{|c|}{ Anamnestic response } \\
\hline $\begin{array}{l}19 \\
28 \\
86 \\
87\end{array}$ & $\begin{array}{l}6.68 \\
6.76 \\
7.13 \\
7.00\end{array}$ & $\begin{array}{c}9.91 \\
11.0 \\
12.1 \\
8.84\end{array}$ & $\begin{array}{l}3.7 \\
3.8 \\
3.7 \\
3.6\end{array}$ & $\begin{array}{l}2.5 \\
1.9 \\
2.1 \\
2.3\end{array}$ & $\begin{array}{l}0.75 \\
0.90 \\
0.87\end{array}$ & $\begin{array}{l}5.0 \\
6.5 \\
8.1 \\
4.6\end{array}$ & $\begin{array}{l}3.6 \\
3.2 \\
3.5 \\
3.0\end{array}$ & $\begin{array}{l}2.6 \\
2.2 \\
2.7 \\
2.3\end{array}$ & $\begin{array}{l}0.18 \\
0.21 \\
0.27 \\
0.20\end{array}$ & $\begin{array}{l}0.15 \\
0.17 \\
0.25 \\
0.22\end{array}$ & $\begin{array}{l}34 \\
34 \\
26 \\
26\end{array}$ & $\begin{array}{l}0.18 \\
0.21 \\
0.27 \\
0.20\end{array}$ & $\begin{array}{l}0.12 \\
0.14 \\
0.22 \\
0.18\end{array}$ \\
\hline $\begin{array}{l}\text { Mean value } \\
\text { 士SE } \\
\text { Change, \% }\end{array}$ & $\begin{array}{l}6.91 \\
0.10\end{array}$ & $\begin{array}{r}10.5 \\
0.7 \\
+52.0\end{array}$ & $\begin{array}{l}3.7 \\
0.13\end{array}$ & $\begin{array}{c}2.2 \\
-41\end{array}$ & 0.84 & 6.1 & $\begin{array}{l}3.3 \\
0.14\end{array}$ & $\begin{array}{c}2.4 \\
0.12 \\
-27\end{array}$ & $\begin{array}{l}0.22 \\
0.019\end{array}$ & $\begin{array}{l}0.20 \\
0.023 \\
-9.1\end{array}$ & & $\begin{array}{l}0.22 \\
0.019\end{array}$ & $\begin{array}{c}0.17 \\
0.022 \\
-23\end{array}$ \\
\hline
\end{tabular}

* TEA = total exchangeable albumin $\mathrm{C}=$ control study, $\mathrm{E}=$ experimental study.
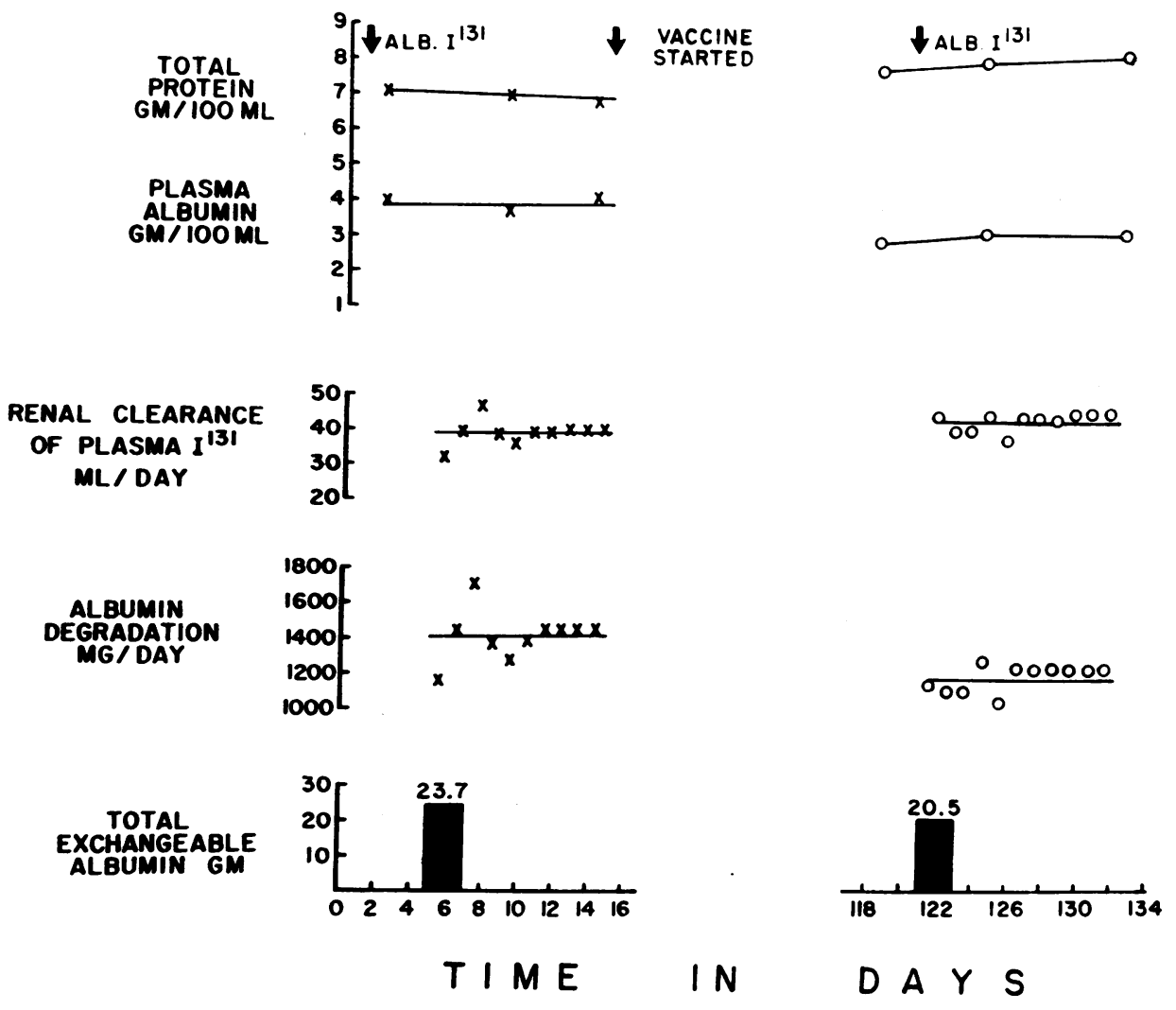

Fig. 1. Typical Rabbit experiment (19) DURING the CONTrol PERIod aNd AFter primary IMMUNIZATION. The total protein concentration increased and the albumin concentration decreased. There was a slight increase in the renal clearance of plasma $\mathrm{I}^{12}$. Albumin degradation decreased and the total exchangeable albumin pool decreased. 

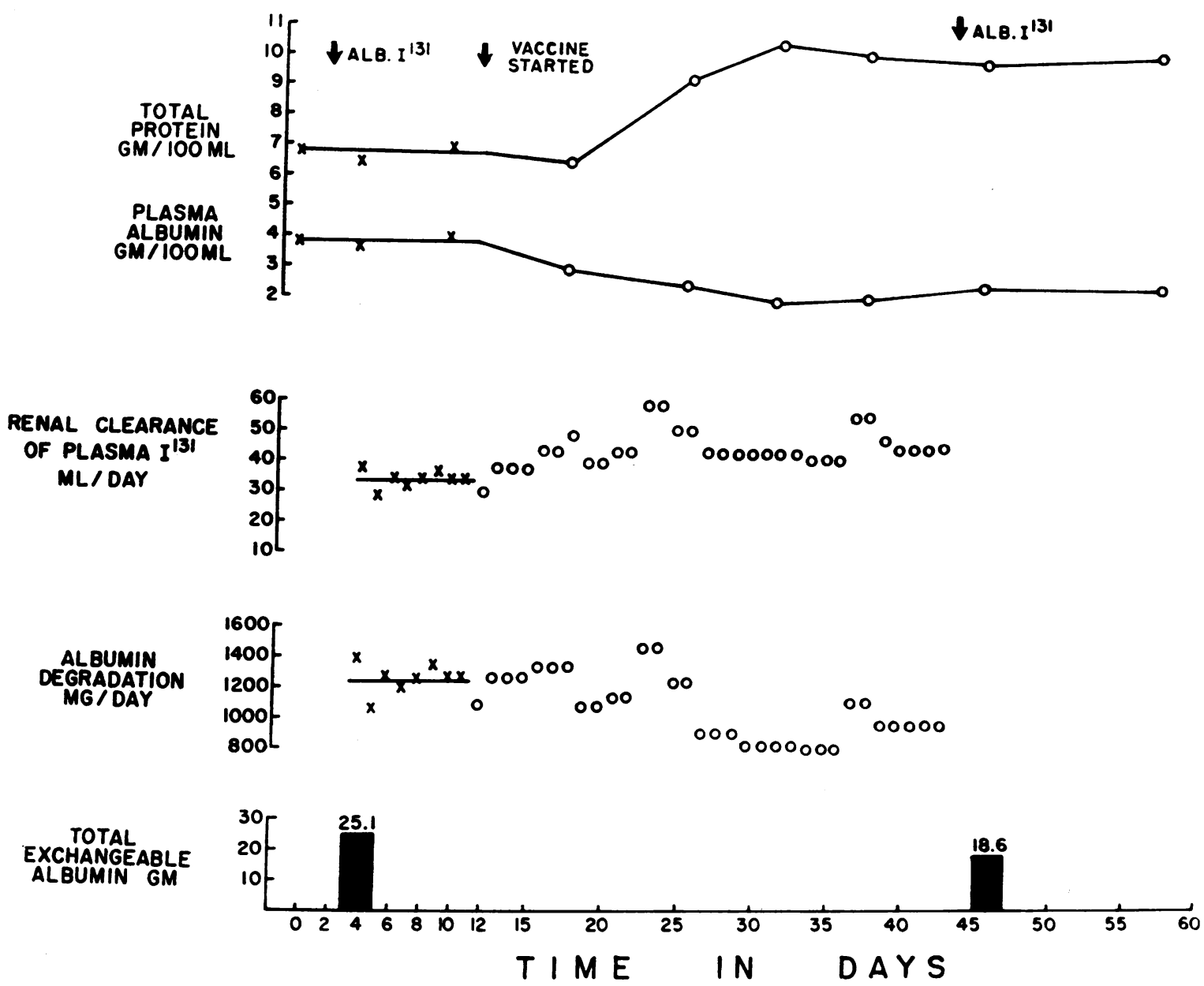

Fig. 2. Typical rabit experiment (19) During the anamnestic response. The total protein concentration increased, and a marked decrease in the albumin concentration occurred. The renal clearance of plasma- $\mathrm{I}^{131}$ rose and there was a decrease in albumin degradation which did not appear until the plasma concentration had decreased to low levels. Total exchangeable albumin decreased.

gain during the 4 to 6 months of vaccine administration following initial immunization injections. The mean plasma volume in the seven rabbits studied after the first immunization period did not differ from the control value. There was, however, a mean increase of 24 per cent in plasma volume in the four animals studied during the anamnestic response. The mean intravascular: extravascular ratio did not differ markedly in either study. The total exchangeable albumin "space" increased by 27 per cent during the anamnestic response to the vaccine.

The data for albumin metabolism are shown in Table II and Figures 1 and 2. After the first immunization period the mean total protein concentration rose 33.2 per cent and was associated with a fall in albumin concentration of 24 per cent. Gamma globulin values ${ }^{1}$ rose from 0.75 to $3.8 \mathrm{~g}$ per $100 \mathrm{ml}$. During the period of re-exposure to the vaccine, total protein rose 52 per cent while albumin concentration decreased by 41 per cent. Gamma globulin concentration rose from 0.84 to $6.1 \mathrm{~g}$ per $100 \mathrm{ml}$.

In the steady state following the first course of immunization, the mean total exchangeable albumin pool fell 22 per cent, and albumin degradation and presumably albumin synthesis decreased 17

1 The control values for $\gamma$ globulin derived from the Kern data are at times difficult to interpret owing to the small number of interference fringes involved. However, the values reported here agree with those reported by others (2) and with the data obtained by paper electrophoresis. 

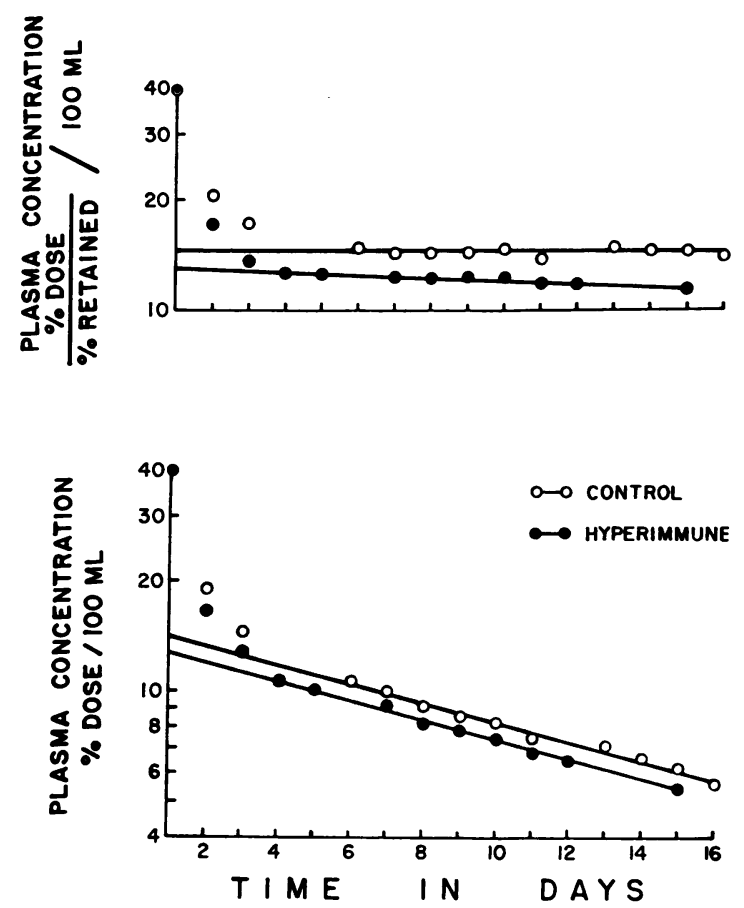

Fig. 3. Typical rabBit experiment (19). The distribution curves (upper graph) reveal a slight increase in the space of distribution after hyperimmunization. The uncorrected plasma concentration curves (lower graph) demonstrate no alteration in the fractional rate of albumin degradation.

per cent from control values. After the second exposure to the vaccine, the mean total exchangeable albumin pool had decreased 27 per cent from the control value immediately before secondary immunization. Albumin degradation (grams per kilogram per day) failed to show any significant change until the plasma albumin concentration had declined considerably, usually by the day 7 to 10 after revaccination. Thereafter, albumin degradation fell to low levels within a few days. The mean value for albumin degradation during the entire experimental period was only 9.1 per cent below that calculated for an equivalent control period. However, albumin degradation during the last 12 days of study, prior to reinjection with albumin$\mathrm{I}^{131}$, averaged $0.17 \mathrm{~g}$ per $\mathrm{kg}$ per day compared with a mean value of 0.22 during the control period. The mean value for albumin synthesis was $0.17 \mathrm{~g}$ per $\mathrm{kg}$ per day, 23 per cent below the control level, suggesting that equilibrium between albumin synthesis and degradation was being established.

The fractional rates of albumin degradation were not altered in either study. After the first immunization period, the mean rate for albumin degradation was 6.8 per cent per day compared with a control value of 6.7 per cent. After the anamnestic response, the mean value was 7.0 per cent per day compared with a control value of 6.7 per cent. $^{2}$

The increase in weight observed during the first immunization period was assumed to be related to normal growth of the animals, and calculations following reinjection of albumin- $\mathrm{I}^{131}$ were based on the observed weight at that time. With a mean weight as the basis for calculations, the plasma volume would have shown a slight increase. Similar calculations would not materially affect the changes reported above in total exchangeable albumin and albumin degradation.

\section{DISCUSSION}

The administration of a polyvalent pneumococcal vaccine is an effective means of producing hyperglobulinemia in rabbits, particularly in animals which are re-exposed to this material. No untoward effects of the vaccine were noted, and all animals behaved normally during both the first immunization course and anamnestic response.

During the first immunization course, some 4 to 6 months of treatment were required before the rabbits demonstrated significant changes in total plasma protein concentration or change in albumin: globulin ratio. By this time, however, there was a significant fall in the absolute rate of albumin degradation. The total exchangeable albumin pool was also lower and thus not only did albumin synthesis fall, but for some period must have been even less than albumin degradation to account for the loss of exchangeable albumin. Although the absolute amount of albumin degraded per day was lower than the control value, the fractional rate for albumin degradation was unchanged from the control (Figure 3 ). It can thus be seen that the fractional turnover rate, per se, will give no indication of changes that occurred in the synthetic and degradative rates at the new steady state.

\footnotetext{
2 This value is calculated from albumin degradation (grams per kilogram per day) divided by the TEA (grams per kilogram). The value for TEA during the anamnestic development of hyperglobulinemia was taken to be the average TEA of the control and experimental period.
} 
During the anamnestic response, hypergammaglobulinemia and hypoalbuminemia developed rapidly, and maximal effects were noticed after 2 to 3 weeks of continued immunization. The decrease in plasma albumin concentrations can be partly explained by dilution, since there was an increase in the total apparent space for albumin distribution. The amount of albumin degraded remained at control levels until the plasma albumin concentration fell. Since the total albumin pool was declining in the face of a constant amount of albumin degraded, there was initially an actual increase in the fractional rate of albumin degradation. These observations indicate that albumin synthesis was deficient during this interval and resulted in the observed decrease in the albumin concentration and total pool of exchangeable albumin. In support of this interpretation of the sequence of events is the finding that albumin degradation fell to low levels at the end of the experimental period just prior to the reinjection of albumin- ${ }^{\mathbf{1 3 2}}$. This level of albumin degradation approximated the calculated daily rate for albumin synthesis determined for the whole experimental period, suggesting that equilibrium between degradation and synthesis was again being approached. The loss in total albumin must have occurred prior to this period.

In evaluating the decrease in albumin synthesis, in the presence of a rapidly increasing globulin production, ${ }^{3}$ the available amino acid pool must be considered. Starvation and malnutrition in children have resulted in a depressed albumin concentration (14). Also, depressed albumin levels have been seen in patients with carcinoma (15). Lowered albumin synthesis has been considered the cause in both conditions $(14,15)$. In addition, there are reports that increased nitrogen intake results in an increased rate of protein turnover $(16,17)$. It seems possible that the stimulation of synthesis of one protein at a rapid rate may, at least temporarily, interfere competitively with

${ }^{3}$ The greater than 7 -fold increase in the plasma concentration of $\gamma$ globulin observed during the mean 30-day anamnestic period indicated a marked increase in $\gamma$-globulin production. Since the degradative rate of $\gamma$ globulin increases in the presence of elevated globulin levels in human subjects (12) and in rabbits (13), the total $\gamma$-globulin synthetic rate certainly exceeds the normal rate by a considerable degree. the synthesis of others, as has been suggested (18, 19).

While albumin distribution was not grossly altered in either study, and the plasma volume remained unaltered after the first immunization, there was an increase in plasma volume associated with the rapid production of hyperglobulinemia during the anamnestic response. This observation would be consistent with the maintenance of equilibrium in osmotic forces that occurs during the slow buildup of globulin levels but not during the rapid development of hyperglobulinemia. In the latter case, albumin synthesis decreased but not rapidly enough to allow for osmotic equilibrium without a change in plasma volume in the presence of the marked increment in circulating $\gamma$ globulin. As a result of the increase in plasma volume, the calculated colloidal osmotic pressure was not significantly altered in spite of the rapid rise in $\gamma$-globulin concentration (Table III).

Albumin degradation decreased in both studies but, during the anamnestic response, only after albumin levels had fallen to low values. This observation agrees with that seen during dextran in-

TABLE III

Calculated plasma colloid osmotic pressure *

\begin{tabular}{lccl}
\hline \hline & Control & Immunized & Difference \\
\hline & $m m \mathrm{Hg}$ & $\mathrm{mm} \mathrm{Hg}$ & $\mathrm{mm} \mathrm{Hg}$ \\
Primary immunization & & & \\
Albumin & 13 & 9.5 & -3.5 \\
Globulin & 1.0 & 4.9 & +3.9 \\
Anamnestic response & & & \\
Albumin & 13 & 7.2 & -5.8 \\
Globulin & 1.1 & 7.9 & +6.8 \\
\hline
\end{tabular}

* It should be emphasized that the results listed in Table III must be only an approximation of the actual state, since rabbit serum proteins may differ somewhat in molecular weight and charge from those observed for human serum proteins and, in addition, the contribution of $\gamma$-globulin to osmotic pressure may differ from the predicted values. However, the interpretation is probably valid, since the rabbits did demonstrate a return toward a new equilibrium state in terms of albumin metabolism and distribution, and it seems reasonable to assume that even if the quantitative values given above are not accurate, the trend toward a colloid osmotic balance is present.

In a previous paper (4) a decrease in plasma albumin concentration of $1.43 \mathrm{~g}$ per $100 \mathrm{ml}$ was reported as being equivalent to a decrease in calculated osmotic pressure of $7.6 \mathrm{~mm} \mathrm{Hg}$. This value should have been $6.0 \mathrm{~mm} \mathrm{Hg}$. This change does not affect the conclusions.

t Albumin molecular weight assumed to be 69,000 with a net charge of -18 at $\mathrm{pH} 7.4(21,22)$.

$\ddagger$ Globulin molecular weight assumed to be 150,000 with a net charge of -8 at $\mathrm{pH} 7.4(21,22)$. 
fusions (4), and suggests that the quantity of the albumin degraded may be related to albumin concentration or pool size.

Such a relationship, however, is not present for albumin synthesis. The presence of a low albumin concentration in both the first and anamnestic immunizations did not result in increased albumin production. Actually, the lowest values for albumin synthesis were associated with the lowest albumin levels. Likewise, the depressed serum albumin levels produced by means of continued dextran infusions were neither accompanied nor followed by an increase in albumin production (4). In addition, the observed dextran-induced depression of albumin synthesis (4) could not be interpreted as being due to an insufficient pool of amino acids, particularly in view of the reported nitrogensparing action of dextran (20). Thus, the available evidence indicates that the actual level of circulating albumin does not act as an appropriate stimulus to albumin synthesis. Albumin, dextran, and $\gamma$ globulin, however, all contribute to colloid concentration, and changes in the concentration of any one of these can affect colloid osmotic pressure. If an osmotic regulatory system exists and acts by exerting control over albumin synthesis, a decrease in albumin synthesis would follow the addition of these macromolecules to the circulation. The present studies indicate such a reciprocal relationship between $\gamma$ globulin and albumin and suggest the following chain of events in globulin and albumin metabolism. If globulin synthesis increases slowly, albumin synthesis decreases slowly until the albumin pool size and concentration are reduced to levels consistent with a normal oncotic pressure with a normal plasma volume. However, when globulin levels rise rapidly, the decrease in albumin synthesis is apparently insufficient to lower albumin levels rapidly enough to prevent the plasma volume expansion. While certain reservations must be retained, the results of the present studies support the concept that colloid osmotic pressure plays an important role in the rate of albumin production.

\section{SUMMARY}

1. By means of a polyvalent pneumococcal vaccine, the effects of hyperimmunization on albumin metabolism were studied in seven female rabbits during a first immunization period and in four female rabbits during an anamnestic response.

2. In the presence of hypergammaglobulinemia, produced slowly during a first immunization period, the plasma volume and total apparent space for albumin distribution were unaltered. Albumin degradation decreased 17 per cent and the albumin pool size by 22 per cent ; albumin synthesis, therefore, must have decreased significantly.

3. During the rapid development of hypergammaglobulinemia, in secondary immunization, there was a 24 per cent increase in plasma volume associated with a decrease in the total albumin pool of 27 per cent and a decrease in albumin synthesis of 23 per cent.

4. The alterations in albumin synthesis observed in the presence of hypergammaglobulinemia are consistent with the concept of an osmotic regulatory mechanism controlling albumin synthesis.

\section{ACKNOWLEDGMENTS}

The authors wish to express appreciation for technical assistance to Miss Carole Evans, Mr. Alvin Burks, Mr. Douglas Faison, Mr. Ramon Flores, Mr. John Tolbert and Mr. Carl Walker; to Miss Amy Roe and Miss Frances Prelli for preparation of the vaccine; and to Miss Margaret Tobin for secretarial assistance. Some of the vaccine used in this study was obtained from Dr. Morris Rakietan, South Shore Analytical \& Research Laboratory, Inc., Islip, New York.

\section{REFERENCES}

1. Bjфrneboe, M., and Schwartz, M. Investigations concerning the changes in serum proteins during immunization. The cause of hypoalbuminemia with high gamma globulin values. J. exp. Med. 1959, 110, 259.

2. Bjфrneboe, M., and Jarnum, S. The changes in serum proteins and blood volume during immunization. J. exp. Med. 1961, 113, 1005.

3. Ogryzlo, M. A., Maclachlan, M., Dauphinee, J. A., and Fletcher, A. A. The serum proteins in health and disease. Filter paper electrophoresis. Amer. J. Med. 1959, 27, 596.

4. Rothschild, M. A., Oratz, M., Wimer, E.. and Schreiber, S. S. Studies on albumin synthesis: The effects of dextran and cortisone on albumin metabolism in rabbits studied with albumin- $\mathrm{I}^{131}$. J. clin. Invest. 1961, 40, 545.

5. Rothschild, M. A., Schreiber, S. S., Oratz, M., and McGee, H. L. The effects of adrenocortical hormones on albumin metabolism studied with albumin- $\mathrm{I}^{131}$. J. clin. Invest. 1958, 37, 1229. 
6. Berson, S. A., Yalow, R. S., Schreiber, S. S., and Post, J. Tracer experiments with $\mathrm{I}^{131}$ labeled human serum albumin: Distribution and degradation studies. J. clin. Invest. 1953, 32, 746.

7. Berson, S. A., and Yalow, R. S. Distribution and metabolism of $\mathrm{I}^{131}$ labeled proteins in man. Fed. Proc. 1957, 16, suppl. 1, 13S.

8. Zizza, F., Campbell, T. J., and Reeve, E. B. The nature and rates of excretion of radioactive breakdown products of $\mathrm{I}^{131}$-albumin in the rabbit. J. gen. Physiol. 1959-60, 43, (part I), 397.

9. Berson, S. A., and Yalow, R. S. Quantitative aspects of iodine metabolism. The exchangeable organic iodine pool, and the rates of thyroidal secretion, peripheral degradation and fecal excretion of endogenously synthesized organically bound iodine. J. clin. Invest. 1954, 33, 1533.

10. Rothschild, M. A., Bauman, A., Yalow, R. S., and Berson, S. A. The effect of large doses of desiccated thyroid on the distribution and metabolism of albumin- $\mathrm{I}^{131}$ in euthyroid subjects. $J$. clin. Invest. 1957, 36, 422.

11. Block, J., Durrum, E. L., and Zweig, G. A. A Manual of Paper Chromatography and Paper Electrophoresis. New York, Academic Press, 1958.

12. Mills, J. A., Calkins, E., and Cohen, A. S. The plasma disappearance time and catabolic half-life of $\mathrm{I}^{131}$-labeled normal human gamma globulin in amyloidosis and in rheumatoid arthritis. J. clin. Invest. 1961, 40, 1926.

13. Catsoulis, E. A., Rothschild, M. A., Franklin, E. C., Oratz, M., and Schreiber, S. S. Unpublished observations.
14. Gitlin, D., Cravioto, J., Frenk, S., Montano, E. L., Galvan, R. R., Gomez, F., and Janeway, C. A. Albumin metabolism in children with protein malnutrition. J. clin. Invest. 1958, 37, 682.

15. Steinfeld, J. L. $\mathrm{I}^{131}$ albumin degradation in patients with neoplastic diseases. Cancer 1960, 13, 974.

16. Jeffay, H., and Winzler, R. J. The metabolism of serum proteins. II. The effect of dietary protein on the turnover of rat serum protein. J. biol. Chem. 1958, 231, 111.

17. Steinbock, H. L., and Tarver, H. Plasma protein. $\mathrm{V}$. The effect of the protein of the diet on turnover. J. biol. Chem. 1954, 209, 127.

18. Berson, S. A., and Yalow, R. S. Serum protein turnover in multiple myeloma. J. Lab. clin. Med. 1958, 49, 386.

19. Verghese, N., Satyanarayana, M. P., Ramakrishnan, P. N., and Kuppuswamy, K. Serum protein fractions in lymphogranuloma venereum. J. Lab. clin. Med. 1958, 49, 370.

20. Jaenike, J. R., and Waterhouse, C. Metabolic and hemodynamic changes induced by the prolonged administration of dextran. Circulation 1955, 11, 1.

21. Scatchard, G., Batchelder, A. C., and Brown, A. Chemical, clinical, and immunological studies on the products of human plasma fractionation. VI. The osmotic pressure of plasma and of serum albumin. J. clin. Invest. 1944, 23, 458.

22. Cohn, E. J., Oncley, J. L., Strong, L. E., Hughes, W. L., Jr., and Armstrong, S. H., Jr. Chemical, clinical and immunological studies on the products of human plasma fractionation. I. The characterization of the protein fractions of human plasma. J. clin. Invest. 1944, 23, 417. 